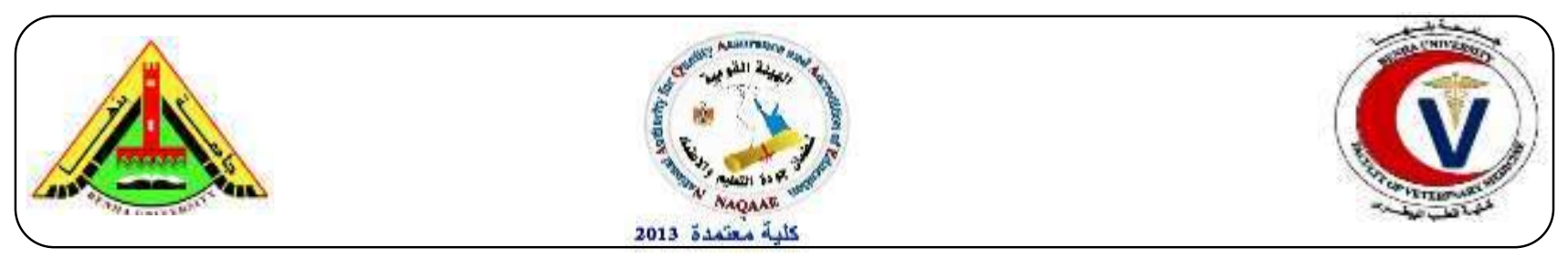

\title{
Assessment of Heavy Metal Residues in Some Fishery Products
}

\author{
Dalia Mohamed Shawky EI-Dahman', Mohamed Ahmed Hassan ${ }^{2}$, Nesreen zakrya eleiwa ${ }^{1}$ \\ ${ }^{1}$ Department of Food Hygiene, Animal Health Research Institute, Dokki, Giza \\ ${ }^{2}$ Department of Food Hygiene, Faculty of Veterinary Medicine, Benha University
}

\section{A B S T R A C T}

To estimate the levels of mercury and lead in fishery products, one hundred random samples of frozen fish, salted sardine, fesiekh and canned tuna (25 of each) were collected randomly from different fish markets in Kafr El-Sheikh and Gharbia governorates, Egypt. The obtained results revealed that the mean values of mercury and lead $(\mathrm{mg} / \mathrm{kg})$ were $(0.38 \pm 0.01$ and $0.29 \pm 0.01)$ in frozen fish $(0.61 \pm$ 0.01 and $0.47 \pm 0.01)$ in salted sardine, $(0.79 \pm 0.01$ and $0.71 \pm 0.01)$ in fesiekh and $(1.03 \pm 0.02$ and $0.90 \pm 0.01)$ in canned tuna, respectively. The levels of mercury and lead were significantly $(\mathrm{p}<0.05)$ higher in canned tuna and fesiekh than salted sardine and frozen fish. Moreover, the majority of the examined fish samples, particularly, canned tuna and fesiekh exceeded the safe permissible limits. In this respect, $(48 \%, 40 \%)$ and $(44 \%, 32 \%)$ of the examined samples of canned tuna and fesiekh and $(36 \%, 24 \%)$ and $(28 \%, 20 \%)$ of the examined samples of salted sardine and frozen were above the maximum permissible limits recommended by EOS (2010) for mercury and lead, respectively. As conclusion, the examined samples of canned tuna and fesiekh were significantly polluted with high levels of toxic metals (mercury and lead) which seriously distress human health.

Keywords: Heavy metal, lead, mercury, salted sardine, canned tuna.

Received: 19 June 2019, Accepted: 12 July 2019 (http://www.bvmj.bu.edu.eg)

(BVMJ-36(2): 49-56, 2019)

\section{INTRODUCTION}

Fish and fish products occupy one of the foremost places among the food products of animal origin in their nutritive value and this may be attributed to their contents of high biological value protein, lipid, vitamins and essential fatty acids as well as, it provides Omega-3 fatty acids, which have many health benefits (Darwish et al. 2003). On the other hand, fish have the ability to accumulate heavy metals in their tissues by the absorption along the gill surface and gut tract wall to higher levels several hundred times more concentration of metals in their surrounding than the water medium (Daviglus et al., 2002 and Burger and Gochfeld, 2005).

Toxic elements can be very harmful even at low concentration when ingested over a long time period. The essential metals can also produce toxic effects when their intake is excessive (Celik and Oehlenschager, 2007). The heavy metals content of fishery products need to be well established as fishery products are widely consumed by humans. Since fish is the last link in the aquatic food chain, the heavy metal concentrations in many fish species have been determined in relation to the metal 
content of the aquatic environment. Industrialization has improved general technology as well as quality of life but has also resulted in an increase in metal concentrations in water (Tarley et al. 2001).

Fish can be preserved in so many ways including freezing, salting, pickling, smoking and drying. But the most useful way of preserving seafood is through canning.

The main threats to human health from heavy metals are associated with exposure to mercury, cadmium and lead, due to their known toxicity to human being, even at low concentrations when ingested over a long period (Oehlenschläger, 2005). These toxicants accumulate in the body, especially in liver leads to defects in cellular uptake mechanism in the mammalian liver and kidney and inhibit hepatic and renal sulfate/bicarbonate transporter through various mechanisms, leading to sulfaturia following heavy metal intoxication. Furthermore, freezing or heat treatment of fish for long period of time cannot destroy the heavy metals. Thus, there is great risk associated with consumption of the frozen fish (Dhatrak and Nandi 2009).

Therefore, the current study is performed for detection of some heavy metal residues in some fish products like frozen fish, canned tuna, fesiekh and salted sardine to determine their validity for human consumption.

\section{Materials and methods}

\subsection{Collection of samples:}

A total of one hundred random samples of fish products represented by frozen fish, salted Sardine, Fesiekh and canned Tuna (25 of each) were collected at different times from various fish markets in El-Gharbia and kafr-Elsheikh governorate, Egypt. All samples of frozen fish and canned Tuna were collected within their validity date. All collected samples were analyzed by Atomic Absorption
Spectrophotometer "AAS" (UNICAM969AA) for estimation of their heavy metals concentrations (mercury and lead). 2.2. Determination of heavy metals (wet digestion technique):

The samples were prepared and digested according to the technique described by (Lars, 2003 and Staniskiene et al. 2006). Washing of equipment is an important process to avoid contamination especially when trace elements or heavy metals are to be analyzed. Briefly, one gram from each sample of dorsal muscle was digested by $10 \mathrm{ml}$ of digestion mixture $(60 \mathrm{ml}$ Nitric acid $65 \%$ and $40 \mathrm{ml}$ Perchloric acid 70$72 \%$ ) in screw capped tube after maceration by sharp scalpel. The tubes were tightly closed and the contents were vigorously shacked, stand overnight at room temperature and heated for 4 hours in water bath at $70^{\circ} \mathrm{C}$ to ensure complete digestion of samples. Cooled samples were diluted with $10 \mathrm{ml}$ deionized water, thoroughly mixed, filtered with Whattman filter paper and kept at room temperature until analyzed for heavy metal contents. Blank and standard solutions were prepared in the same manner. Digested samples, blanks and standard solutions were analyzed for mercury and lead contents.

\subsection{Calculation and statistical Analysis:}

Mercury absorbency was recorded directly from the digital scale of AAS and its concentration was calculated according to the following equation:

$$
\begin{aligned}
& \mathrm{C}_{1}=\left(\mathrm{A}_{1} / \mathrm{A}_{2}\right) \times \mathrm{C} \times(\mathrm{D} / \mathrm{W}) \mathrm{mg} / \mathrm{kg} \\
& \text { Where, }
\end{aligned}
$$

$\mathrm{C}_{1}=$ concentration of mercury $(\mathrm{mg} / \mathrm{kg})$ wet weight.

$A_{1}=$ Absorbency reading of sample solution.

$\mathrm{A}_{2}=$ Absorbency reading of standard solution.

$\mathrm{C}=$ Concentration of mercury on the standard solution.

$\mathrm{D}=$ Dilution factor of sample.

$\mathrm{W}=$ weight of each sample.

While, the concentration of lead was estimated according to the following equation: $\mathrm{C}=\mathrm{R} \times(\mathrm{D} / \mathrm{W})$ 
Where,

$\mathrm{C}=$ concentration of lead $(\mathrm{mg} / \mathrm{kg})$ wet weight.

$\mathrm{R}=$ reading of digital scale of AAS.

$\mathrm{D}=$ Dilution of prepared sample.

$\mathrm{W}=$ Weight of the sample.

\section{RESULTS}

The results presented in table (1) and figure (1) showed that the mean values of mercury were $(0.38 \pm 0.01),(0.61 \pm 0.01),(0.79 \pm 0.01)$ and $(1.03 \pm 0.02) \mathrm{mg} / \mathrm{kg}$ in frozen fish, salted sardine, fesiekh and canned tuna samples, respectively. Statistical analysis revealed a significant $(\mathrm{P}<0.05)$ higher mercury content was in canned tuna and fesiekh than salted sardine and frozen fish, Moreover, (24\%), $(36 \%),(40 \%)$ and $(48 \%)$ in frozen fish, salted sardine, fesiekh and canned tuna samples, respectively, were found to exceed the permissible limits $(0.50 \mathrm{mg} / \mathrm{kg})$ recommended by EOS (2010).

The results presented in table (2) and fig, (2) showed that mean values of lead were $(0.29 \pm$ $0.01),(0.47 \pm 0.01),(0.71 \pm 0.01)$ and $(0.90 \pm$ $0.01) \mathrm{mg} / \mathrm{kg}$ in frozen fish, salted sardine, fesiekh and canned tuna samples, respectively. Statistical analysis revealed a significant $(\mathrm{P}<0.05)$ higher lead content was in canned tuna and fesiekh than salted sardine and frozen fish $(0.47 \pm 0.01$ and $0.29 \pm 0.01)$. Moreover, $(20 \%),(28 \%),(32 \%)$ and $(44 \%)$ in frozen fish, salted sardine, fesiekh and canned tuna samples, respectively, were found to exceed the permissible limits $(0.3 \mathrm{mg} / \mathrm{kg})$ recommended by EOS (2010).

Table 1: Concentrations of mercury $(\mathrm{mg} / \mathrm{kg})$ in the examined fish products and their acceptability $(n=25)$

\begin{tabular}{lcccccccc}
\hline Fish products & $\begin{array}{c}\text { MRL } \\
(\mathrm{mg} / \mathrm{Kg})\end{array}$ & \multicolumn{2}{c}{$\begin{array}{c}\text { Accepted } \\
\text { samples }\end{array}$} & $\begin{array}{c}\text { Unaccepted } \\
\text { samples }\end{array}$ & Min & Max & Mean \pm S.E \\
& & No. & $\%$ & No. & $\%$ & & & \\
\hline Frozen fish & 0.5 & 19 & 76 & 6 & 24 & 0.12 & 0.96 & $0.38 \pm 0.01$ \\
Salted Sardine & 0.5 & 16 & 64 & 9 & 36 & 0.19 & 1.24 & $0.61 \pm 0.01$ \\
Fesiekh & 0.5 & 15 & 60 & 10 & 40 & 0.30 & 1.51 & $0.79 \pm 0.01$ \\
Canned Tuna & 0.5 & 13 & 52 & 12 & 48 & 0.37 & 1.78 & $1.03 \pm 0.02$ \\
\hline
\end{tabular}

$\operatorname{EOS}(2010) *$ 
Table 2: Concentrations of lead $(\mathrm{mg} / \mathrm{kg})$ in the examined fish products and their acceptability $(n=25)$.

\begin{tabular}{lcccccccc}
\hline Fish products & $\begin{array}{c}\text { MRL } \\
(\mathrm{mg} / \mathrm{Kg})\end{array}$ & \multicolumn{2}{c}{$\begin{array}{c}\text { Accepted } \\
\text { samples }\end{array}$} & $\begin{array}{c}\text { Unaccepted } \\
\text { samples }\end{array}$ & Min & Max & Mean \pm S.E \\
& & No. & $\%$ & No. & $\%$ & & & \\
\hline Frozen fish & 0.3 & 20 & 80 & 5 & 20 & 0.09 & 0.68 & $0.29 \pm 0.01$ \\
Salted Sardine & 0.3 & 18 & 72 & 7 & 28 & 0.13 & 0.85 & $0.47 \pm 0.01$ \\
Fesiekh & 0.3 & 17 & 68 & 8 & 32 & 0.21 & 1.19 & $0.71 \pm 0.01$ \\
Canned Tuna & 0.3 & 14 & 56 & 11 & 44 & 0.28 & 1.36 & $0.90 \pm 0.01$ \\
\hline
\end{tabular}

$\operatorname{EOS}(2010) *$

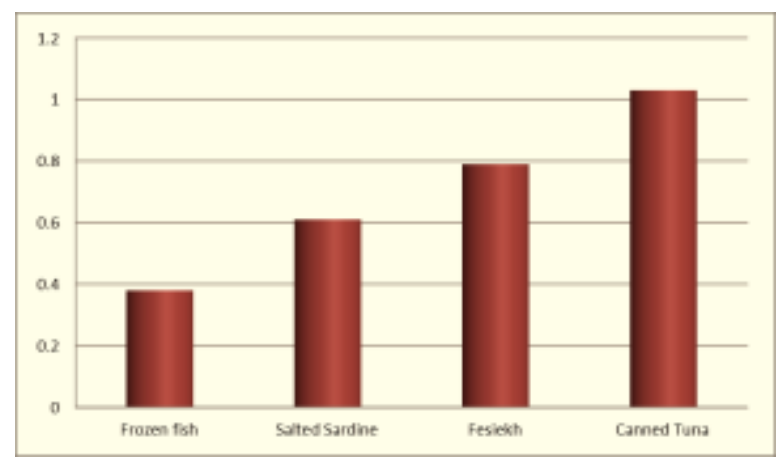

Fig.1. Mean values of mercury residues $(\mathrm{mg} / \mathrm{Kg})$ in the examined samples of fish products.

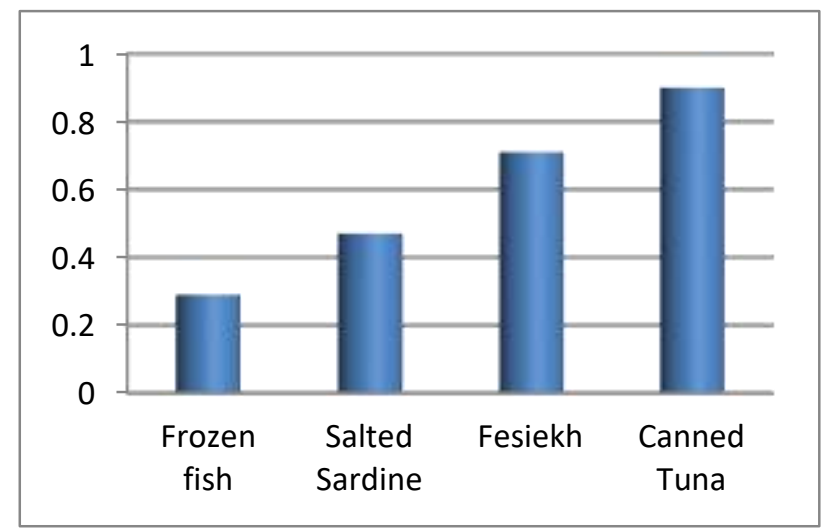

Fig.2. Mean values of lead residues $(\mathrm{mg} / \mathrm{Kg})$ in the examined samples of fish products.

\section{DISCUSSION}

Heavy metals are considered as serious pollutants to aquatic ecosystems due to their long-term persistence, toxicity, bioaccumulation, and biomagnification along the water, sediments and aquatic food chain causing loss in fish populations (Yi et al. 2011 and Omar et al. 2013).

Canned products especially canned tuna have been found to contain increasingly high amounts of mercury, lead and cadmium as well as some other heavy metals. These metals are considered the most important form of 
pollution of the aquatic environment because of their toxicity and accumulation by marine organisms; and also because of their persistent and being not easily biodegradable in nature. Metal pollution of the sea is less visible and direct than other types of marine pollution but its effects on marine ecosystems and humans are intense and very extensive (Emamikhansari et al. 2005).

Salted fish by industrial salt had greater concentrations of most studied metals than those of fresh and salted fish by analytical one (Yosef and Gomaa, 2011).

The results presented in table (1) and figure (1) showed that the concentrations of mercury ranged from (0.12 to 0.96$)$, (0.19 to 1.24$)$, (0.30 to 1.51 ) and (0.37 to 1.78$) \mathrm{mg} / \mathrm{kg}$ in frozen fish, salted sardine, fesiekh and canned tuna samples, respectively. Statistical analysis revealed a significant $(\mathrm{P}<0.05)$ higher mercury content in canned tuna and fesiekh $(1.03 \pm 0.02$ and $0.79 \pm 0.01 \mathrm{mg} / \mathrm{kg}$ ) than salted sardine and frozen fish $(0.61 \pm 0.01$ and $0.38 \pm 0.01$ $\mathrm{mg} / \mathrm{kg})$. Moreover, (24\%), (36\%), (40\%) and $(48 \%)$ in frozen fish, salted sardine, fesiekh and canned tuna samples, respectively, were found to exceed the permissible limits $(0.50$ $\mathrm{mg} / \mathrm{kg}$ ) recommended by EOS (2010).

The result of mercury $(\mathrm{mg} / \mathrm{kg})$ in frozen fish was nearly similar to Oluyemi and Olabanji (2011) (0.41 \pm 0.01$)$, while higher concentration was recorded by Andreji et al. (2005) $(2.85 \pm 1.22)$ and lower concentration was reported by Islam et al. (2010) (0.24 \pm 0.007$)$.

The result of salted sardine was higher than that recorded by Sallam and El-Gazzar (1997) $(0.253 \pm 0.037)$ and lower than that recorded by Latif (2018) (1.26 \pm 0.13$)$.

Lower results of mercury were recorded by Sallam and El-Gazzar (1997) (0.212 \pm 0.7$)$ and Salah El-Dien et al. (2005) (0.143) $\mathrm{mg} / \mathrm{kg}$.
While, high result was recorded by Latif (2018) $(1.59 \pm 0.16)$.

Higher results were obtained by Storelli et al. (2002) (1.375) $\mathrm{mg} / \mathrm{kg}$, lower result by Storelli et al. (2000) (0.15) $\mathrm{mg} \mathrm{kg}$.

Mercury can accumulate in human body through eating of fish and other marine organisms. Mercury is one of the most toxic elements has neurotoxic effect (Agusa et al. 2005). In 2001, pregnant women and women of child bearing age should not eat longerliving and larger fish that feed on other fish such as shark, swordfish, mackerel and tilefish, the average of methyl mercury of each species is above $0.7 \mathrm{mg} / \mathrm{g}$, because they may contain enough methyl mercury which lead to fetus nervous system damage (FDA, 2001)

Methyl mercury is a highly toxic substance. The adverse health effects associated with exposure to it have been identified in human and in animal studies. The most extensive risky effects of mercury are the data on neurotoxicity, particularly in developing organisms. Fetus, infants and young children generally are more sensitive than adults to the neurological effects of methyl mercury (EPA, 2012).

Minamata disease is sometimes referred to as Chisso- Minamata disease. It is a neurological syndrome caused by severe mercury poisoning. The cause of this disease was the release of methyl mercury in industrial wastewater, this highly toxic chemical bioaccumulated in shellfish and fish in MinamataBay in japan which when eaten by the local population resulted in mercury poisoning (Minamata Disease Archives, 2006).

Lead is one of the most ubiquitous metals known to humans. It reaches the aquatic system because of superficial soil erosion, atmospheric deposition. 
The results presented in table (2) and fig, (2) showed that lead level $(\mathrm{mg} / \mathrm{kg})$ ranged from (0.09 to 0.68$),(0.13$ to 0.85$),(0.2$ to 1.19$)$ and (0.28 to 1.36) in frozen fish, salted sardine, fesiekh and canned tuna samples, respectively. Statistical analysis revealed a significant $(\mathrm{P}<0.05)$ higher lead content in canned tuna and fesiekh $(0.90 \pm 0.01$ and $0.71 \pm 0.01)$ than salted sardine and frozen fish $(0.47 \pm 0.01$ and $0.29 \pm 0.01)$. Moreover, $(20 \%)$, (28\%), (32\%) and (44\%) in frozen fish, salted sardine, fesiekh and canned tuna samples, respectively, were found to exceed the permissible limits $(0.3 \mathrm{mg} / \mathrm{kg})$ recommended by EOS (2010).

The results of lead in frozen fish were lower than Oluyemi and Olabanji (2011) (0.43 \pm $0.01) \mathrm{mg} / \mathrm{kg}$, and higher than Amin (2011) $(0.09 \pm 0.01) \mathrm{mg} / \mathrm{kg}$.

These results were lower than Daoud and Abd El-Aziz (2002) (0.275 \pm 0.044$) \mathrm{mg} / \mathrm{kg}$ but high result was recorded by El-kewaiey et al. (2011) $(2.097 \pm 0.224) \mathrm{mg} / \mathrm{kg}$,

These results agree with that recorded in salted fesikh salted by analytical salt and lower than that salted by industrial salt (Yosef and Gomaa, 2011) (0.448 to 1.226$) \mathrm{mg} / \mathrm{kg}$ and higher result recorded by Salah El-Dien et al. (2005) revealed a higher residual level (5.951) $\mathrm{mg} / \mathrm{kg}$.

These results were nearly similar to Morshady et al. (2013) $(0.127 \pm 0.02) \mathrm{mg} / \mathrm{kg}$, while higher result recorded by Celik and Oehlenschlager (2007) (0.076 to 0.314$) \mathrm{mg} / \mathrm{kg}$ and lower result obtained by Khansari et al. (2005) (0.0366) mg/kg.

The main sources of lead are diet, old lead based paint, lead in soil and dust from contaminated leaded paint and gasoline, mining and industrial activity, indoor floor dust, hand - to - mouth behavior, concurrent malnourishment and pica activity in children and lead smelting. Crops grown in soils contaminated with lead residues from pesticides or atmospheric lead and packaged in cans made with lead solder, lead emissions from petrol, improperly prepared infant formula, metal welding, car accumulators and lead - containing scraps and sewage effluents (ATSDR, 2007). Lead has hepatotoxic effects and showing significant increase in liver function test parameters (Adeyemi et al. 2009).

The main sources of lead are diet, old lead based paint, lead in soil and dust from contaminated leaded paint and gasoline, mining and industrial activity, indoor floor dust, hand - to - mouth behavior, concurrent malnourishment and pica activity in children and lead smelting. Crops grown in soils contaminated with lead residues from pesticides or atmospheric lead and packaged in cans made with lead solder, lead emissions from petrol, improperly prepared infant formula, metal welding, car accumulators and lead - containing scraps and sewage effluents (ATSDR, 2007). Lead has hepatotoxic effects and showing significant increase in liver function test parameters (Adeyemi et al. 2009).

\section{CONCLUSION}

The current study proved that there are great variations in the levels of mercury and lead in the examined samples of fish product. In addition, the examined samples of canned tuna and fesiekh were significantly polluted with high levels of toxic metals affecting the human health. In other words, the continuous consumption of these contaminated fish may result in public health hazard through progressive irreversible accumulation of such toxic pollutants in the human body.

\section{REFERENCES}

Adeyemi, O.; Ajayi, J.O.; Olajuyin, A.M.; Oloyede, O.B.; Oladiji, A.T.; Oluba, O.M.; Adeyemi, O.; Ololade, I.A. and Adebayo, E.A.(2009): Toxicological 
evaluation of the effect of water contaminated with lead, phenol and benzene on liver. Kidney and colon of Albeno rats. Food chemToxicol., 47(4):885-887.

Agency for Toxic Substance and Disease Registry (ATSDR) (2007):

Toxicological Profile for Lead U.S. Department of Health and Humans. Services, Public Health Humans Services, Centers for Diseases Control. Atlanta.

Agusa, T.; Kunito, T.; Iwata, H.; Monirith, I.; Tana, T.S.; Subramanian, A. and Tanabe, S. (2005): Mercury contamination in human hair and fish from Combodia. Levels specific accumulation and risk assessment. Environ. Pollut. 134: 79-86.

Amin-Reham, A. (2011): Heavy metal residues in imported frozen fish and Pangasius hypophthalmus (Basa) fish fillets. Benha Vet. Med. J., 2:14-22.

Andreji, J.; Stranai, Z.; Massonyl, P. and Valent, M. (2005): Concentration of selected metal in muscle of various fish species. J. Environ. Sci. Heal. 40(4):899-912.

Burger, J. and Gochfeld, M. (2005): Heavy metals in commercial fish in

New Jersey. Environmental Research, 99: 403 $-412$.

Celik, U. and Oehlenschlager, J. (2007): High contents of Cadmium, lead, zinc and copper in popular fishery products sold in Turkish supermarkets. Food control, 18: $258-261$.

Daoud-Jehan, R. and Abd El-Aziz, A.H.B. (2002): Determination of some heavy metal residues in salted and smoked fishes. Vet. Med. J. Giza 50:547-556.

Darwish, A.M.; El-Mossalami, M.K. and ElBassuony, R.A. (2003): Qual-ity assurance of some fatty fishes. Assuit vet. M.J. 49(98): 79-96.

Daviglus M, Sheeshka J. and Murkin E. (2002): Health benefits from eating fish. Comments Toxicol 8(4-6):345-374.

Dhatrak, S.V. and Nandi, S.S. (2009): Risk assessment of chronic poisoning among Indian metallic miners.Indian J. Occup. Environ. Med. 13: 60-64.

Egyptian Organization for Standardization "EOS" (2010): Maximum levels for certain contaminants in foodstuffs. No 7136/2010. Egyptian Standards, Ministry of Industry, Egypt.

El-Kewaiey, I.A.; Ali-Omima, I. and SalehOmima, A. (2011): Incidence of heavy metals residues in salted and smoked fish products. Assiut vet. Med. J. Vol. 57 No. (131): 92-108, Egypt.

El-Tahan, M.H.; Hassan, S.A.; El-Awamry, Z.K. and Hamza, A.S. (1999): Studies of some heavy metals and nutritive values in salted fish in Egypt. J. Egypt. Ger. Soc. Zool., 29(A): 41-53.

EmamiKhansari, F, M. Ghazi-Khansari. and M. Abdollahi (2005): Heavy metals content of canned tuna fish Food Chem., 93 : 293-296.

EPA "Environmental Protection Agency" (2012): Elemental mercury used in barometers, manometers, hygrometers, and psychrometers, significant new use rule, overview of mercury and mercury uses. Federal Register/ Vol. 77, No. 104

FDA "Food and Drug Administration" (2001): Scombrotoxin histamine formation. $\mathrm{Ch}$. 7. In: Fish and Fishery products Hazards and Controls Guidance. 3rd Ed., p. 83102 .Food and Drug Administration, Center for Food Safety and Applied Nutrition, Office of Sea Food, Washington, DC.

Islam, M. M.; Bang, S.; Kyoung-Woong, K.; Ahmed, M. K. and Jannat, M. (2010): Heavy metals in frozen marine fish of Korea. Journal of scientific research, 2 (3), 549-557.

Khansari, F.E.; Ghazi-Khansari, M. and Abdollahi, M. (2005): Heavy metals content of canned tuna fish. Food Chemistry, 93 (2): 293-296.

Lars, J. (2003): Hazards of heavy metal contamination. British Med. Bull. 68: 167-182.

Latif, H. (2018): Detection of Some Heavy Metals in Fresh and Salted Fish. M.V.Sc.Thesis, (meat hygiene), Fac. Vet. Med., Banha Univ., Egypt.

Minamata Disease Archives (2006): National Institute for Minamata disease, retrieved 29 October, http:// www.nimd.go.jp/archives.

Morshdy, A. E. M. A.; Hafez, A. E. E.; Darwish, 
W. S.; Hussein, M. A. M. and Tharwat, A. E. (2013): Heavy metals residue in canned fish, Faculty of Veterinary Medicine, Zigzag University, Japanese Journal of Veterinary Research S54-S57.

Oehlenschläger, J. (2005): Identifying heavy metals in fish. In: Safety and Quality Issues in Fish Processing. Ed: Bremner, H.A. WoodheadPublishing Limited and CRC Press LLC. pp. 95-108.

Oluyemi, E.A. and Olabanji, I.O. (2011): Heavy metals determination in some species of frozen fish sold at Ile-Ife main market, South West Nigeria. Ife Journal of Science, Vol. 13, No. 2.

Omar WA, Zaghloul KH, Abdel-Khalek AA and Abo-Hegab S (2013): Risk assessment and toxic effects of metal pollution in two cultured and wild fish species from highly degraded aquatic habitats. Arch Environ. Contam. Toxicol., 65: 753-764.

Salah El-Dien, W.M.; Makhouf-Manal, M. and Abd El-Fattah, M.E (2005): Residual analysis of some heavy metals in salted fish (Feseakh) in Sharkia governorate. Zag. Vet. J., 33(1): 248-254.

Sallam, Kh.I. and El-Gazzar, M.M. (1997): Heavy metal residues in salted and smoked fish marketed at Zagazig City. Alex. J. Vet. Sci., 13(5): 525-532.

Staniskiene, B.; Matusevicius, P.; Budreckiene, P. and Skibniewska, K.A. (2006): Distribution of heavy metals in tissues of freshwater fish in Lithuania. Polish J. Environ Studies, 15(4): 585-591.
Storelli, M.M. Storelli, A. and Mareotrigiano G.O (2000): Heavy metals in muscles (Mytilus galloprovincialis) from the Ionian Sea, Italy, J. Food Ports, 63(2):273-276.

Storelli, M.M. Stuffier, R.G. and Mareotrigiano, G.O. (2002): Total and methyl mercury residues in tuna - fish from the Mediterranean Sea. Food Additives and Contaminants, Vol.N0 8: $715-720$.

Tarley, C.R.T. W.K.T. Coltro, M. Matsushita and de Souza, N.E. (2001): Characteristic levels of some heavy metals from Brazillian canned sardines (Sardinellabrasiliensis). Journal of Food Composition and Analysis, 14: 611-617.

Yi, Y.; Yang, Z. and Zhang, S. (2011): Ecological risk assessment of heavy metals in sediment and human health risk assessment of heavy metals in fishes in the middle and lower reaches of the Yangtze River basin. Environ. Pollut., 159(10): 2575-2585.

Yosef, T.A. and Gomaa-Ghada, M. (2011): Assessment of Some Heavy Metal Contents in Fresh and Salted (Feseakh) Mullet Fish Collected from El- Burullus Lake, Egypt. J. Amer. Sci., 7(10):137144. 